\title{
WESTERN BALKANS AS EU PERIPHERY: IS IT TIME FOR CHANGES?
}

\author{
DOI: http://dx.doi.org/10.18509/GBP.2018.34
}

UDC: 339.92(4-672EУ:497-15)

\section{Goran Mutabzija}

Faculty of Philosophy, University of East Sarajevo, Pale, Bosnia and Herzegovina

\begin{abstract}
This paper emphasizes an importance of the EU and its periphery and asks a question about the position of Western Balkan? Where the borders of the EU and what are is its periphery [8]? What is today's perspective of region with 18 million inhabitants and joint GDP of USD 89.1 billion equal with half of Portugal's [12]? Precise answer to these questions is no, but based on Eurostat data for 2011 the EU has 507 million inhabitants, and 504 million neighbours. They live on the perimeter of the Arctic to Algeria, the four partially related entities. The" Centre" of the entire region is the Western Balkans or South-Eastern Europe (1), the" East" is represented by the countries of the former Soviet Union without the republics of Central Asia (2), the "South" is the Afro-Asian Mediterranean area (3), and the "North" are Faeroe Islands and Greenland; Norway and Iceland are the part of EFTA (there are even Switzerland and Liechtenstein) and are not considered peripherals. The EU periphery is diverse in all respects: economic, social, cultural and natural geographic and Western Balkans is an atypical space EU periphery on two grounds. - As a region with the highest level of multiculturalism it has always been a meeting point or a clash of civilizations (Orthodoxy, Catholicism and Islam), and at the same time (as opposed to other regions) has no energy resources. The question then arises as to of all the Western Balkan countries with a view to extending the conditions for admission to the EU or is this only extended time without the sincere wish that this region becomes a part of the EU?
\end{abstract}

Keywords: Western Balkans, Bosnia and Herzegovina, EU periphery, Enlargement, Specificity, Perspectives.

\section{INTRODUCTION}

Europe's relations with its neighbours are neither static nor uniform and varied during the past decades. The main challenges facing today's Europe is reflected in this area in the various elements such as: international competitiveness, the impact of climate change, energy security, an aging population, biodiversity and civilisation diversity. The influence of the EU in its neighbourhood is reduced and part of the problem with its periphery is moved into "their garden". Contemporary relations between the EU and its periphery can be seen in the light of various economic and political model of the world, where the polarization of the "rich North-poor South" is simplified. This is especially true for the "South" where political passion caused by "Arab Spring" does not subside and the consequences (the exodus of the population) spill over into Europe. In addition, the domain of economic relations has resulted in changes, establishment of new partnerships 
but also in improving macroeconomic indicators "periphery" while the EU for 15 years has stagnated. ${ }^{3}$

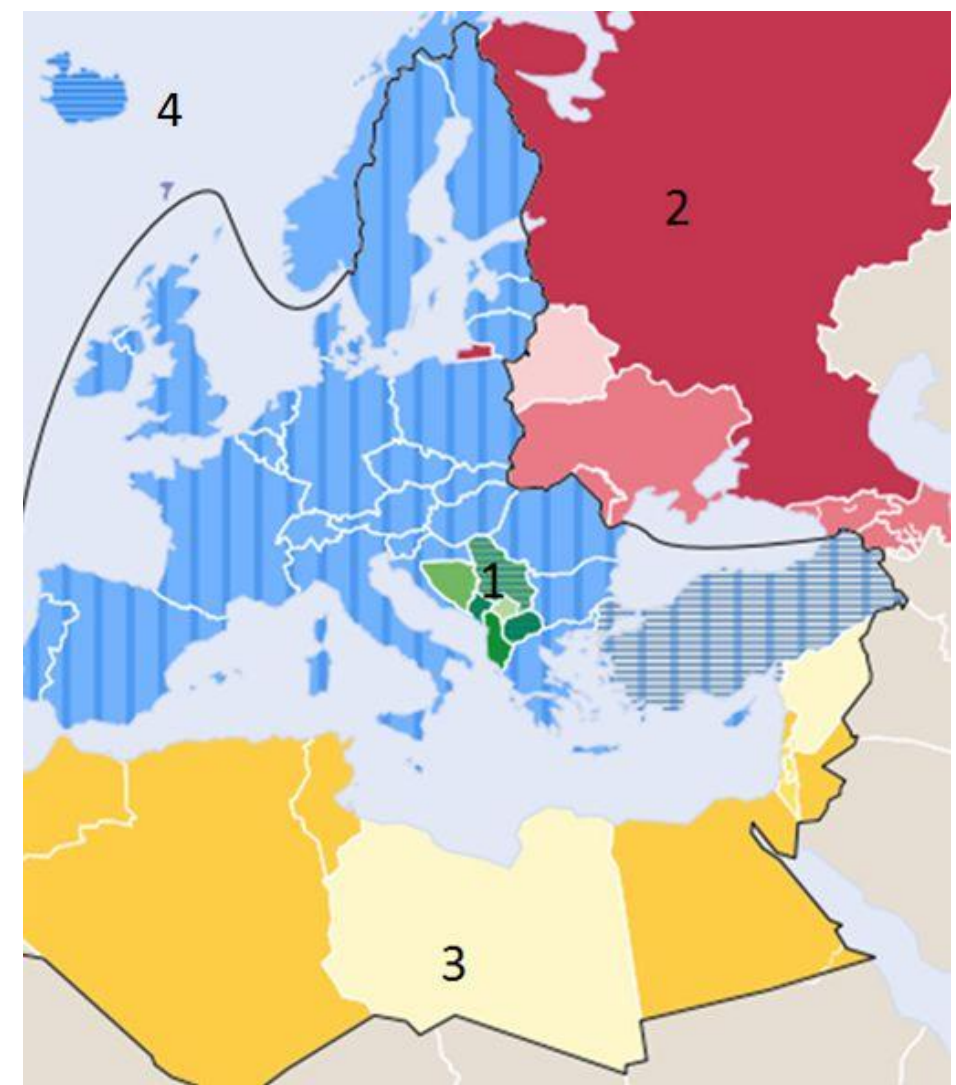

Figure 1. EU periphery: The W. Balkan, the East, the Mediterranean and the Atlantic. (Adapted from ESPON)

One of the major economic issues is energy, because it is crucial for the security of Europe and its development. The EU is faced with two problems, lack of sufficient quantities of cheap and environmentally friendly energy and the fight against air pollution (reducing greenhouse gas emissions). The EU does not have a sufficient amount of its own energy sources, and some of the world's reserves are located in the periphery (North Sea, Siberia, North Africa and the Middle East), except on the Balkans. The dependence of the energy sources of hydrocarbons (oil and gas) increases greenhouse gas emissions and the use of nuclear energy is considered to be sufficiently safe and many countries have, therefore, entered the phase out 4 . Thus, territorial cooperation through the convergence of Europe's regions and neighbouring territories may create mutual benefits, since there are strong links that are shaped by different historical and cultural influences of European regions and neighbourhoods, for example Denmark with Faroe Islands and Greenland, the countries of Central Europe with the countries of Eastern and Southeastern Europe, Spain, France and Italy with the countries of North Africa, the United Kingdom with Middle East countries. It includes many of the disputed territory and a multitude of minority groups with their different economic and demographic potential

\footnotetext{
${ }^{3}$ According ESPON (2014) while the overall GDP per capita of the Neighbourhood countries was only US\$ 2000 per year in 1994, it was US\$ 8000 by 2011.

${ }^{3}$ Phasing out nuclear plant was first started in Austria 1978 and then Sweden, Germany, Belgium, Spain.
} 
thus creating a complex mosaic in which there is no simple geopolitical solutions and without that the long-term peace and harmonious development which means conditio sine qua non. In economic terms, as emphasizes, there is a clear interest of good relations and the EU periphery, based on partnerships, which can be expressed by participation of these markets in European with "Neighbourhoods are important partners, accounting $7.5 \%$ in the trade of goods, $7 \%$ of European air connections, absorbing $15 \%$ of the European aid of development, providing 30\% of immigration into Europe and providing a third of the energy supply of the European market. EU relations with the periphery" are crucial to its energy strategy, because "energy dependence of the EU by 2025 will reach $65 \%$ and in the domain of gas $80 \%$ " [8].

Europe is mostly surrounded by exporters of energy and with the exception of Norway, all EU countries and EFTA countries are obliged to import energy. While Russia had the greatest total energy exports in 2011, Algeria, Saudi Arabia, Iraq, Kuwait, the UAE and Azerbaijan had the greatest exports of energy in relation to their own needs. Today, European countries that produce energy or serve as transit countries, similarly depend on the markets of European consumers, while a significant increase in energy demand is expected in the countries of the Mediterranean in the upcoming decades. Peripherals are an important market for the EU, because trade and market opportunity represent $11 \%$ of the potential growth markets in Europe for the next decade.

The EU's role in the trade with all parts of the periphery is in decline. The reason for this is the strong transformation of economies on the periphery of the EU which is characterized by specialization and high competitiveness. Fifty years ago, the EU was generally surrounded by exporting countries low accumulative products (mining, agricultural products and partially energy), while the EU exported goods and services of high value. Today, EU member states surrounded by countries that exported mainly energy and only a few countries have an export focus on the textile industry and are growing direct competition for these sectors within the EU (Turkey, Morocco).

\section{THE WESTERN BALKANS AND THE ENLARGEMENT PROCESS}

Europe and the EU are the two concepts that do not have the same meaning and territorial definition. The geographic boundaries of the continent are unquestionable and the notion of the EU in the literature is often cited as its equivalent, which is incorrect. The EU's borders have variable categories and in political and geographical terms, this notion tends to include a space that is wider than the continent (economic dimension), equal to the continent (political dimension) and narrower than the European space (cultural dimension). Specific of this region is mix of different cultures but "multiculturalism is not a mark for a society that contains different cultural groups. The name "cultural pluralism" is more appropriate for such a society. Multiculturalism is a policy or a series of political measures - refers to political programs that accept the authenticity of different lifestyles within a community and seek to promote their beneficial and positive interactions relations - but within the framework of a comprehensive, unified civilian system rights and obligations" [1].

In Europe, there are 740 and the EU 504 million inhabitants where the community does not belong mainly to the state in the East and Southeast of Europe and by one state in the centre and north of Europe. "The political process of expansion of EU borders is called expansion (enlargement) whose complexity of the process is easily seen through the historical development of three successive stages: the "post-Berlin" 1991-01, "EU- 
phoria" 2002-13 and "EU-restraint" 2014-20. The first phase began after the fall of the "Berlin Wall" in 1989 and the collapse of the Soviet Union in 1991 after which Europe is reunited and sets a new economic and social challenges and horizons to non-EU countries" [4].

It emerged from the political divisions, which entailed not only differences in economic organization, but the entire social system. Since then, democratic Europe has grown from 22 to 42 members so that the scope of the Council of Europe has 770 million people accounting for $14 \%$ of world population. With the accession of new states, economic disparities between the member states of the Council of Europe have increased.

"In the first 14 Member States, GDP / PPP per capita stood at \$20,000 while in the 11 new, less than $\$ 5,000$. The Council of Europe in 1997, in response to marked social differences, has declared social cohesion as one of the most important needs of an enlarged Europe" [4]. That is why, after the adjustment and gradual implementation of the ESDP, the Pan-European Conference of Ministers responsible for spatial planning in the framework of the Council of Europe in Hanover, adopted a strategic document on the principles of the future spatial development of Europe.

The second phase of the "EU-phoria 2002-13" coincides with the 6th and 7th EU budgetary framework in which most of the planned program is implemented, notably EU enlargement to the East in 2004 (10 countries), 2007 and $2013(2+1)$. Unfortunately, the economic crisis which started in 2008 interrupted a fantastic economic and social development of the EU and announced that in the third phase (2014-20) there will be no enlargement of the EU, but many projects will be reduced and the help of "Non- EU member states" limited. It is in this economy, while the country seeks to accelerate "reforms" and approached their political goal, that some EU member states faced bankruptcy and the exodus of migrants from Afro-Asian world to Europe takes on huge proportions in the long run (running a few tens of millions of migrants from Morocco to Afghanistan).

"In 2016, the region's total trade with the EU was over EUR 43 billion, up 80\% since 2008 and with significant further growth potential. EU companies are also the biggest investors in the Western Balkans, with over EUR 10 billion of Foreign Direct Investment in the region in the past five years alone. The interlink age and interdependence of the region with the European Union was evident in the migration crisis. The countries of the region are increasingly acting as partners on the global stage" [9].

\section{SPECIFICS OF BOSNIA AND HERZEGOVINA}

Bosnia and Herzegovina is a complex country that is politically organized as a community of two entities and three nations5. Unsuccessful processes such as rising economic backwardness, political instability and the absence of EU perspective produced growing EU scepticism. Internally, there is no political consensus between the three nations about modalities of further development. Political parties that gather the majority Bosniaks want

\footnotetext{
${ }^{4}$ According Dayton Peace Agreement (1995) Bosnia and Herzegovina (BiH) consists of two entities: Federation of $\mathrm{BiH}(\mathrm{FBiH}) \&$ Republic of Srpska (RS). The population census was conducted in 2013 and anecdotal evidence that of 3.53 million inhabitants has $50.1 \%$ of Bosniaks (Muslims), 30.7\% Serbs (Orthodox) and $15.4 \%$ Croats (Catholics). Because of the desire of some NGOs to fictitiously increase the number of Bosniaks people from the Diasporas as a resident person, although they live abroad for more than 20 years. Because of this, there are no agreement entity's Institutes for statistics to verify these results.
} 
to change the Dayton Peace Agreement in the direction of centralization of the state and the weakening of entities; Serbian political representatives want the preservation of the RS and the political representatives of Croats are dominantly for the third entity (predominantly Croatian). With the current level of economic development and many problems of social nature, it is difficult to expect consensus on many issues and the increase in violence and terrorist activities was evident. ${ }^{6}$ Its reason why EC strongly recommended "a reinforced engagement on counter-terrorism and radicalisation should include strengthening strategic, legislative and institutional capacities in partner countries, building on dedicated counter-terrorism dialogues and joint action plans, and continuing the deployment of counter-terrorism expertise in the Western Balkans" [9].

According to economic analysis that was conducted by the UN in 2010, considerable geographic disparities exist within society in $\mathrm{BiH}$. An analysis was conducted on a regional level in 7 distinct areas and 19 indicators were used for regional ranking: " 89 out of 142 of municipalities and cities $(62 \%)$ in $\mathrm{BiH}$ were either underdeveloped or extremely underdeveloped. Every sixth household in the country is poor and no major improvement in poverty reduction in the country has been achieved since 2000" [6].

The most developed region in the RS is Banja Luka and Eastern Sarajevo, in $\mathrm{FBiH}$ cantons: Sarajevo, Herzegovina and Zenica-Doboj. Also, the least developed regions in the FBiH are: cantons 10, Una-Sana, Bosnia-Drina and Bijeljina region in RS. It should be added that number of employees (2010) was $21.9 \%$, unemployed $40.6 \%, 18.2 \%$ of the population lived below the poverty line and the value of GINI index stood at 33.3. Also, the development of Bosnia and Herzegovina is characterized by a lack of investment with foreign direct investment (FDI) what is of a great importance. In a nutshell, the remains of the old value system is insufficient, civil wars degraded infrastructure and industry, the privatization of social goods is carried out in a bad way and outdated technology need to be innovated. For the period 2008-12, the average annual share of FDI inflows to GDP in $\mathrm{BiH}$ was only $3 \%$, the lowest in the region. The average value of GDP per capita in $\mathrm{BiH}$ in 2010 amounted to 3287 Euro. Taking into account the spatial distribution of basic economic parameters, we can see a very bad deal in the mountainous region. This is general assessment for all mountainous areas across the region where the population density is very low (there is no economic volumes for sustainable development), stressed that the emigration and aging of population, and with inadequate infrastructure and the dominance of the primary sector (extensive agriculture and forestry) and distance market (urban centres), those regions are threatened by depopulation. "At the state level there is $1.6 \%$ of households with no income; $34.3 \%$ have only one source of income while $64.1 \%$ of households have two or more sources of income. Basic indicators of living standards, such as: salary ( $385 €)$, the average monthly expenses $(847 €)$, connection to the sewage network (47.7\%), water supply (94.1\% households) are not satisfactory. As many as 32 persons / 1,000 inhabitants are refugees or displaced persons which further complicates the overall social and economic ${ }^{7}$ picture [6].

\footnotetext{
${ }^{5}$ Only in autumn 2015 were recorded several terrorist acts with 3 deaths, effected as attacks on the police stations and military barracks.

${ }^{6}$ Demography, Education, Access to Utilities, Quality of Life and Standard of Living, Transportation Infrastructure and Health, Employment and Economic Disparity, Income and Poverty and Social Inclusion and Vulnerable Groups,
} 
According to the economic activity "the most dynamic sectors are: agriculture $9.8 \%$, industry $25.9 \%$ and services $64.3 \%$, and the backbone of economic development are agriculture, power supply and forestry" [11]. Agriculture is characterized by inadequate technological equipment and productivity, measured per unit area, the amount of work and capital is low compared to neighbouring countries and EU averages. With insufficient irrigation systems very frequent natural disasters make enormous damage to commercial farms (mainly in lowland terrain) and the number of small farms is inadequate (highlands). The consequences are economic decline of a large number of agricultural producers and food imports, as one of the largest items in the overall imports. Therefore, all strategies of economic development are focused on improving the living conditions of the entire population and thus stable development.

\section{PROSPECTS FOR THE REGION}

In the Western Balkans, these countries Montenegro, Serbia, Albania and the former Yugoslav Republic of Macedonia have the status of candidate countries and potential candidates are Bosnia and Herzegovina and Kosovo*. "The value of GDP per capita in 2013 in the EU27 amounted to $€ 25,700$ expressed in purchasing power standards (GDP PPS) 12.970" [10]. It is obvious that in the Western Balkans the value of $28 \%$ to $40 \%$ of the EU average represents clear opportunities and economic status of the region.

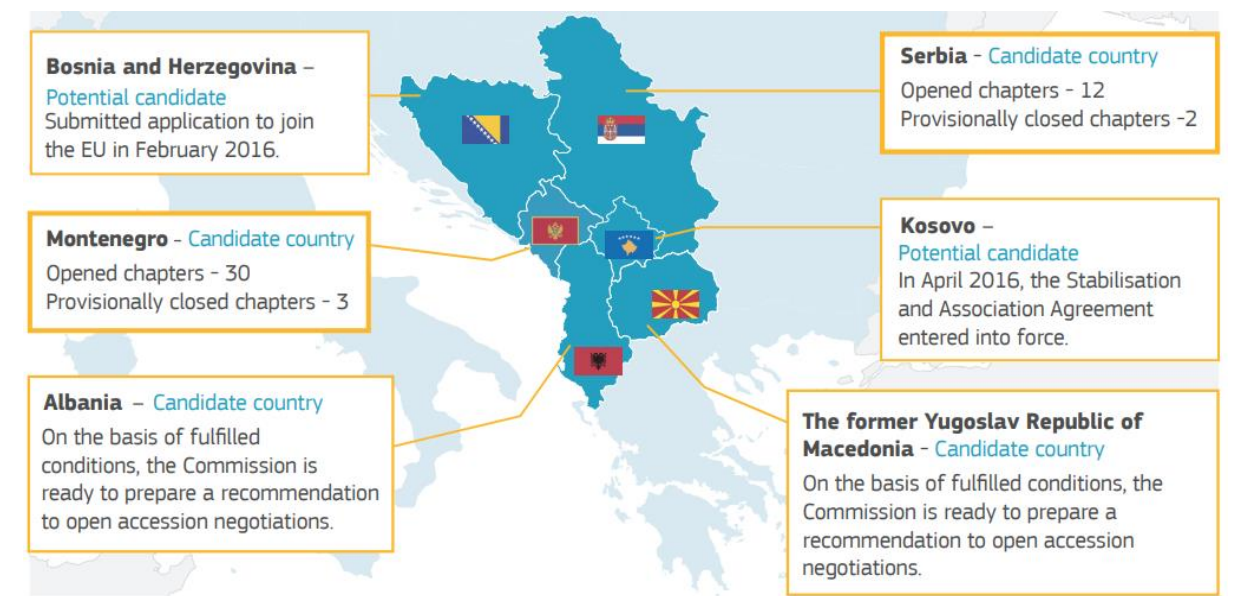

Figure 2. Overview of the EU relations with the Western Balkans in the EU accession process (2018).

Source: http://ec.europa.eu

Montenegro has the smallest population but the highest GDP per capita and low unemployment rate. Serbia has the largest population and the highest economic potential. GDP grew 6\% per annum in the period 2003-08 but the growth has dropped to $1.2 \%$ in period 2008-12. Whatever GDP per capita it is only a third of the EU average, and the unemployment rate amounted to $24 \%$ of the workforce in 2012. The Former Yugoslav Republic of Macedonia has a population of a little more than 2 million inhabitants. Its GDP grew 5\% per annum in the period 2003-08 and 2\% in the upcoming years. The unemployment rate is very high (31\%), and GDP per capita is similar in Serbia (35\% of the EU average). Potential candidate countries had a GDP per capita between $23 \%$ and $30 \%$ of the average. Albania had the lowest unemployment rate $(14 \%)$ while rates in Bosnia and Herzegovina (29\%) and Kosovo (35\%) were significantly higher than EU average. Only one of the 6 countries (Albania) has an employment rate above $50 \%$ for 
the population aged 15-64. In Bosnia and Herzegovina this rate was only $40 \%$ in 2012 and in Kosovo less than a quarter of the working age population had been employed.

In the process of EU accession these countries were available from four financial instruments: PHARE, ISPA, SAPARD and CARDS instrument, which were replaced with a single pre-accession instrument IPA from 2007. The financial framework of this fund in the period (2007-2013) for the region was 11.4 billion Euros. Funds have been established for candidate countries approaching EU membership to reach the level of democratic and economic development and the level of social security which permanent member states had to reach for many years or decades.

Table 1: Overview of GDP PPS 2009-13 in \% of EU average

\begin{tabular}{lllllll}
\hline STATE & 2009 & 2010 & 2011 & 2012 & 2013 \\
\hline Montenegro & 41 & 40 & 41 & 39 & 40 & \\
\hline Serbia & 37 & 36 & 36 & 37 & 37 & \\
\hline Macedonia & 35 & 35 & 34 & 34 & 36 & \\
\hline Bosnia & 27 & 27 & 28 & 28 & 29 & Source: Eurostat \\
\hline Albania & 29 & 28 & 28 & 28 & 28 &
\end{tabular}

Besides inadequate socio-economic aspects which characterize the reality of all countries in the region, further burdening factor is the refugee crisis that coincided with the "Western Balkan Route" that goes Vardar-Morava valley (Macedonia-Serbia) to central Europe across which in 2015 has more than 500,000 immigrants passed. Indubitably, this big political-geographical process will essentially determine the stability of the entire region.

\section{FINAL THOUGHTS}

The Western Balkan countries are in an extremely unfavourable situation which is reflected in several ways. The most obvious is the poor socioeconomic status of countries which coincide with the economic crisis in the EU which significantly reduces the possibility of generous economic assistance to the region. Another important factor is the saturation of the population of the EU with enlargement process because it has negative effects on their national economies. The most negative impact on the enlargement process has a political-geographical aspect which comprises two components: the culturalcivilisation and security. The first embodies predominantly Orthodox-Muslim population of these countries and the other coincides with a superficial equalization of Islam with terrorism.

The positive aspect of this extension can be viewed in a logical and geographical rounding of the political process (expansion) of the geographical boundaries of the continent (Balkan). The second important component has far-reaching significance concerning the civilization of tying Catholic (dominant EU) and the Orthodox and Muslim civilization over the Western Balkan to the relaxation of geopolitical relations in Europe. The third positive component can be demographic. An educated population of the Western Balkan may be a good link between western technology and a way of life with a new market and thereby creating a safer and more prosperous Europe. Hopefully, Balkan is going to be a space of domination "geopolitics of emotion and hope" [3] rather than a "clash of civilizations". 


\section{REFERENCES}

[1] Gidens, E. Evropa u globalnom dobu, Beograd: Clio, 2007.

[2] Martin, P. The Geography of Inequalities in Europe, Spatial Disparities and Development Policy, The World Bank, Berlin Workshop Series, 2009: 239-258

[3] Mojsi, D. Geopolitika emocija, Beograd: Clio, 2009.

[4] Mutabdzija, G. Evropski izazovi - od geografskih ka inovativnim regijama, Istočno Sarajevo: Zavod za izdavanje udžbenika, 2016.

[5] Streeck, W. Neo-Voluntarism: A New European Social Policy Regime“, European Law Journal, Volume 1, Issue 1, 1995.

[6] Šabanović, E. et al. Regional Disparity Assessment in Bosnia and Herzegovina, United Nations in Bosnia and Herzegovina, Report, 2010.

[7] Triandafyllidou, A. Addressing Cultural, Ethnic and Religious Diversity Challenges in Europe - A Comparative Overview of 15 European Countries, Brussels, 2010.

[8] European Union, EU Neighbourhoods, Territorial Dynamics in Europe, ESPON No. 11, Brussels, 2014.

[9] European Commission. A credible enlargement perspective for and enhanced EU engagement with the Western Balkans, Strasbourg, COM, 2018.

[10] Eurostat, http://ec.europa.eu/eurostat/

[11] United Nations Country Team in Bosnia and Herzegovina, Progress towards the Realisation of Millenium Development Goals in Bosnia and Herzegovina, Report, 2013.

[12] OECD, Competitiveness in South East Europe: A Policy Outlook 2018, Competitiveness and Private Sector Development, OECD Publishing, Paris.

http://dx.doi.org/10.1787/9789264298576-en 